\title{
Reassessing REDD: governance, markets and the hype cycle
}

\author{
An editorial comment
}

\author{
Margaret M. Skutsch • Michael K. McCall
}

Received: 26 October 2009 / Accepted: 27 October 2009 / Published online: 13 January 2010

(C) The Author(s) 2009. This article is published with open access at Springerlink.com

With the increasing perception that catastrophic climate change is not just a wild figment of the imagination but a very real possibility, governments and policy makers are searching desperately for effective solutions that are palatable enough to be sold to their electorates. It is not surprising then that a new policy in discussion under the UNFCCC, REDD (Reduced Emissions from Deforestation in Developing Countries), by which reductions in emissions related to deforestation in tropical countries would be rewarded through valuation of the carbon saved, has been embraced with enthusiasm by a wide range of Parties, official observers and the general public (Economist 2009). REDD has already expanded somewhat, now also including forest enhancement, sustainable forest management and forest conservation, under the rubric REDD+. This seems to be an all round winner: cheap carbon reductions (as evidenced by the well-received report of the Stern Commission (2007)), with multiple additional environmental benefits, requiring forest policies and management measures selected by each participating country in line with its own long run objectives for forest management and conservation, and with the potential for participation and benefit sharing by a large number of developing countries and local stakeholders. Although they are still contesting the details of how it should be operationalised and rewarded, many environmental organizations are on board, having jettisoned their earlier doubts about including forest related projects in the international climate agreements. The EU, which does not permit credits from CDM forestry projects within its trading system, is supportive of the idea of REDD+ although still very cautious about a full fledged market-based credit system in the short term.

Indeed, most of the doubts as aired in the international negotiations have not been on technical questions but rather on the policy question of whether REDD/REDD+

M. M. Skutsch $(\varangle) \cdot$ M. K. McCall

Centro de Investigaciones en Geografía Ambiental,

Universidad Nacional Autónoma de México,

Morelia, Mexico

e-mail: mskutsch@ciga.unam.mx 
should be market based or fund based. The distinction between 'market' and 'fund-based' within the current negotiations is not really so much about how the money is raised, but about whether the carbon savings rewarded should be used as offsets against Annex 1 QUELROs or not. In a market based system this would be permitted, in much the same way as CDM CERs are used. In the fund-based systems under discussion, credits would be purchased by a fund, which could be made up of voluntary financial contributions, levies on ERUs or taxes on energy intensive activities and sectors in Annex 1 countries, but they would not be tradable as offsets. The other issue that has been seriously questioned by policy makers is whether REDD should be organized in non-Annex 1 countries at national level (credits being claimed by the state on the basis of overall national achievements during the accounting period) or at sub-national level. While there could be good reasons for a sub-national approach in large countries such as Indonesia and Brazil, where individual states or provinces may have autonomous forest policies, the term 'sub-national' is also confusingly used by some organisations as code for a projectby-project approach in which each project or group of projects markets/funds its own credits individually rather than being rewarded through a comprehensive national system, which is a very different matter. In some sources this is referred to as a 'nested approach', although this is not a very clear descriptor either. Most of the scientific literature on REDD however has focused more on the technical and methodological concerns (monitoring, reporting and verification; baselines, leakage, estimating opportunity costs etc.) than on these policy questions.

\section{The governance gap}

What has been conspicuously lacking both in policy discussions and in the scientific literature is critical analysis of whether countries are actually going to be able to put into practice effective policies and programmes that reverse deforestation and degradation. The range of practical but at the same time politically and socially acceptable actions that countries have at their disposal is in reality not so great. They are required somehow to reduce their rates of deforestation and forest degradation without excessively limiting people's incomes, security and consumption. Any measures they take are likely to affect the livelihoods not only of their forest-dwelling peoples but of all their citizens who make use of forest products, which by definition are currently under-valued. Moreover, the country governments have to take care of the powerful political forces which are disproportionately benefitting from the current systems, whether engaged in logging, ranching, plantations, agricultural expansion or simply in power plays.

The paper by Corbera, Estrada and Brown in this issue is a very welcome contribution on this topic, raising some excellent points and posing some awkward questions. They point out that the challenges are immense, since most of the countries which on paper have the greatest potential to participate in REDD, have in fact had the worst records as regards forest governance in the past through a combination of poorly designed policies, lack of resources for law enforcement, low political interest and corruption. A recent paper by Börner et al. (2009) specifies the argument for the particular case of payments for conservation in the Amazon. Moreover the impacts of the quite considerable spending earlier on forest conservation have been meagre. 
Essentially, the paper by Corbera, Estrada and Brown is questioning whether even the greatly increased quantities of money that REDD could produce will be able to fix these governance gaps, which seems to be the unspoken but underlying assumption of many policy makers and scientists. For while the need for finance for capacity building for REDD is stressed in current literature and in the policy documents, this tends to refer to technical capacity, not political capacity. Deforestation, as Corbera, Estrada and Brown clearly explain, is caused by a complex of policy and economic factors which operate at the national and international levels, rather than the local level where the deforestation actually occurs, and measures to counter these factors would require tough multi-sectoral coordination and policy coherence at national and international levels.

The elephant in the living room here is that there is always purpose behind the deforestation and degradation; the demand for the products and services which are derived from deforestation and degradation has either to be curtailed or substitutes found. The former is a huge political and social cauldron, the latter requires technical and financial investments which are not yet acceptable and have hardly been considered in the REDD debates. The excessively high and unsustainable level of consumption of all kinds of resources by the developed countries, and the excessively high and unsustainable population increases in some, though not all, developing countries, combined with persistence of enormous income inequalities, are the real drivers of loss of forest biomass, but these issues tend to be side-stepped by political leaders and scientists alike.

In many non-Annex 1 countries contemplating participation in REDD, land tenure recognition and entitlements reforms are vital, but there is also much more: in particular, the means to ensure that powerful actors in sectors such as agriculture and infrastructure development cooperate, and the willingness of international buyers of forest and agricultural products to accept the inevitably higher prices that would result. Most countries that are contemplating participating in REDD have not begun to consider the implications of all this. An illustration: the REDD Readiness proposals put forward by around 30 countries for early funding under the World Bank's FCPF programme have mostly been prepared by forestry departments, and they list approaches such as payments for environmental services and improved supervision of conservation areas, but scarcely touch on the underlying problems of forest governance which cut across sectors.

For these reasons, it might in fact be easier for countries to start REDD activities not in those parts of their forest estate which are at most threat from land use change, and where large numbers of credits could be earned if deforestation is reduced, but rather in areas where the loss per hectare is much smaller, but the chance of countering it is more realistic. Most of the discourse on REDD up to now has implicitly referred to large scale deforestation in rainforests. Reducing rates of degradation in the less commercially interesting dry forests that are typically used by local communities would be a much easier proposition politically. Programmes of community forest management have been relatively successful in a number of countries (Nepal, India, Tanzania etc.) and tend not only to reduce degradation but also to increase carbon stocks through steady forest enhancement (which will also be credited, under REDD+). They are supported by the local population because they bring in income and/or increased supplies of subsistence forest products by replacing open access exploitation with a sustainable common property regime. The 
degradation that they combat and the forest enhancement that they promote may count for only a few tons of carbon per hectare per year, but the areas over which they could be implemented are vast, and there are obvious associated development benefits. And while such programmes may require some reforms as regards forest tenure and rights to forests products, but are unlikely to raise major governance conflicts between powerful internal parties.

It is therefore of great importance that reducing degradation is placed centrally in REDD. But although it is included in the agreement, there has been very little discussion on how to operationalise it (how to determine a reference scenario for degradation, for example), and there has been very little discussion at all about forest enhancement, which is essentially 'negative degradation', and how this could be monitored and credited. Parties are still apparently dreaming of the big money they could earn by intervening in the large scale forest clearance that is associated with commercial agriculture and timber exports, heedless of the governance gaps that at present make this near impossible in many countries.

\section{Misconception about the market}

Turning to the two policy dilemmas with which the international negotiations are struggling at present, it is clear that differences of opinion on these issues have their roots in opposing ideological positions and vested interests, and are unlikely to be bridged easily, although there are still many misconceptions which need to be clarified before wise choices can be made. Let us first consider the market-versusfund issue. As regards REDD, mistrust of a market approach is expressed both in local and in global terms.

\subsection{Local concerns about impact of the market on ecological and social outcomes}

One set of concerns relates to fears that a market is fundamentally incompatible with conservation, and that it will in some way negatively impact the ecological and other values of the forest. At a practical level this surfaces in the observation that where markets for forest products are present, forests come under increasing threat. Associated with this is the idea that the conservation of forests requires a holistic approach, and that carbon crediting will lead to lop-sided management in which biodiversity and other forest values are ignored.

The second group of concerns at the local level relate to the rights and welfare of populations ('indigenous people and local communities') that are currently dependent on forest for at least part of their livelihoods. Especially where tenure and rights of access to forest land and products are unclear, there is a risk that these traditional uses of forest, tolerated, if not officially endorsed up to now, could be curtailed by formal decrees to maximize claims of carbon credits by the state or private entities, resulting in forest-dependent people being thrown out and losing their entitlements.

Proponents of a fund approach argue that a fund would mitigate both of these sets of locally situated dangers, since it would be socially and ecologically conscious and more benevolent than the market. It would be managed by experts (as with the GEF for example), and probably with participation of a consultative group, and its decisions would be made professionally rather than on the basis of market 
self-interest. However, as Corbera, Estrada and Brown point out, a fund is unlikely to be able to garner nearly enough money to finance REDD on a sufficient scale, given the sources that are currently proposed for it in the negotiations.. But in any case there is some doubt about whether a fund would in fact be any superior to a market in terms of local impacts. The market proposed for REDD credits is not a freewheeling, neo-lib type of market in which anything goes: far from it. It is much more likely to be a highly regulated market in which checks and balances are imposed: not only to avoid 'hot air' through verification of the quantity of each carbon claim, but also using a variety of indicators with respect to the 'quality' of the carbon. Much can be learned from the CDM mechanism in this respect. Above all it would be an attempt to reduce the excesses of the market that the forest finds itself facing today, by fighting it on its own terms, so to speak.

Applications by countries to a REDD fund on the other hand would be likely to be highly politicized, and it would be naïve in a world of geo-politics to assume that funds would be disbursed on simple grounds of merit. Parties that are supporting a market approach are mostly those who are tired of the bureaucracy involved and the dependency created in their relations with large funding programmes and agencies. They seek trade, not aid, albeit in a controlled trading system. At the forest floor, it would probably not make much difference to local environmental or social outcomes whether the money came from the market or from a fund. However, for governments, the difference could be enormous. Moreover it is quite possible that the overheads of administering a fund would exceed the transaction costs in the market by a considerable margin, even in a market with in-built controls and safeguards on the 'quality' of carbon.

\subsection{Global concerns about the integrity of REDD offsets}

Global worries about a forest carbon market mostly concern the integrity of carbon saved by REDD, in particular the question of permanence, the fear that reduced rates of deforestation credited in one period may be cancelled out by increased rates of deforestation in a subsequent period, as a result of the instability of carbon stocks in above ground biomass and soil. From this the conclusion is derived the notion that forest carbon cannot safely be used as permanent offsets. This argument is put forward frequently in the international debate, in which savings from reductions in use of fossil fuels by contrast are seen as secure. The argument that forest carbon is any different from fossil fuel carbon in this respect may however be deeply flawed.

Stocks of fossil fuels exist underground: in exercising fuel economy of various kinds, we slow down the rate at which these fuels are extracted and converted into atmospheric carbon dioxide. However, eventually the stocks will all be utilized: our climate change strategies only involve slowing down the annual rate at which this happens. Exactly the same is true of forest carbon. What we are aiming for is delaying of emissions so that they occur over a more extended time period. A worst-case scenario would involve the total clearance of all tropical forest but the greater the extent to which this can be spread over time, the less the impact on climate. The main difference in fact between converting fossil fuel stocks and forest carbon stocks to atmospheric carbon is that released forest carbon stocks are always in principle reversible through plantation, while no one has yet found of way of recreating coal, gas and oil on short order (pace carbon capture and storage). 
On the other hand, leakage is a serious concern. A national approach to REDD deals with the issue of leakage within the country, but international leakage could be rampant. As forest clearance becomes more difficult in one country due to its REDD policies, demand for agricultural and timber products may switch to countries which are not participating, as happened in SE Asia after Thailand introduced stricter conservation measures in the 1990s. However, this kind of international leakage is not limited to forest carbon. Tougher environmental legislation in Europe has been one of the factors behind the flight of its heavy industries to developing countries, resulting in reduction of emissions in the part of the world where they are controlled and an increase where they are not.

A third global concern about forest carbon credits entering into a market is that these might be available in such large quantities and at such low prices that fossil fuel carbon projects would not be able to compete. But as Corbera, Estrada and Brown point out, the cost of forest carbon is still very uncertain, and if we start to take into account the costs of the improved governance that will be necessary to produce these credits, the supply is unlikely to overwhelm the demand. Moreover it is clear that QUELROs (or the domestically determined reduction targets that may replace these) need to be planned with the option of REDD credits in mind, with correspondingly deeper cuts. The promise of REDD credits could in fact be a spur to countries to adopt more challenging targets, in itself clearly a good thing.

Finally there is the worry that in a market system, the more powerful players may grab the lion's share, as has been the case with CDM (irreverently known as the 'China Development Mechanism' in some circles). Countries which have relatively good data on their forest stocks and sufficient technical manpower (Brazil, Mexico) will be able quickly to take advantage of a REDD market while others fall behind. A colourful recent footnote to this debate is the concern, apparently put about by Interpol, that international mafia may become involved in fraudulent trade in carbon credits (Reuters 2009), and scams have been reported from Papua New Guinea already (The Age 2009). It is however inevitable that countries that are better prepared will be better able to take advantage of international schemes such as REDD, and this will happen whether the money is disbursed by a market or by a fund run by one of the international environmental agencies. The primary aim is to reduce carbon emissions as quickly as possible, and equity considerations should focus firstly on ensuring that vulnerable people within the participating countries are not being done down by the scheme, rather than trying to iron out international inequalities. Of course, an international fund could and should exist for REDD-readiness to help the countries with less capacity to climb on board, but to expect the major fund for forest carbon reductions to right the wrongs of an inequitable world would not be sensible, indeed it could be a recipe for policy failure.

\section{The 'national versus sub-national' debate}

The second major international policy dilemma relates to the national-versus-subnational debate. As pointed out earlier, the terminology of this debate is confused, because at one level it is not about national versus decentralized government approaches, despite its title, but about an approach controlled by government (at whatever level) versus one largely controlled by non-government actors. The 
national approach bundles the outcome of all REDD efforts within the national territory together, for the purpose of claiming credits or funds by the country (though clearly there could also be scope for states or provinces within large countries like Indonesia and Brazil to participate as units); the 'sub-national' might allow individual projects to sell or fund their carbon reduction efforts externally and independently. This later approach is preferred by some prominent international environmental NGOs, but is not supported by many non-Annex 1 Parties, who are generally anxious to gain more political and economic control over their nation's forests via the REDD mechanism. The different positions on this issue of course reflect the different roles that these different institutions play; environmental agencies frequently take contracts to manage individual projects, while governments hope to earn enough on carbon credits nationally to fund the major policy interventions needed. The argument for a sub-national approach is however officially made in terms of lack of technical, and, especially, political capacity at the national level; whereas the argument for a national approach is made in terms of the need to avoid internal leakage and cherry picking the easiest project areas.

If REDD is to make a significant difference to emissions, a strong nationally based approach which recognises and rewards local forest management is clearly essential, not just to control for leakage but precisely because of the governance issues which underlie deforestation, which can only be sorted out at that level. There is plenty of scope for national government ministries in forestry to provide stimulus, incentives and technical assistance to community or project level forest management. Support to the legality of community forests and entitlements of communities to their products under sustainable management agreements, combined with equitable distribution of carbon payments are the first steps towards implementing an effective national REDD system.

\section{Step by step to REDD through the hype cycle}

Solutions to complex dilemmas in international decision making are usually found by putting off the big decisions and adopting a one step at a time experimental or learning approach. For the case of REDD this is almost certainly what is in the pipeline. Successive phases are proposed: a preparatory phase in which countries wishing to participate in REDD are provided with technical assistance to build up their capacity, largely to handle the considerable data requirements that full participation in REDD will require, but also giving time to develop adequate national level policies. At the same time, specifically funded REDD pilot projects are likely to be initiated for learning purposes, which may be useful as regards lessons about local governance, management, monitoring and the nuts and bolts of local payment systems, although unfortunately they are not likely to throw much light on the bigger governance issues such as inter-sectoral competition for land. In a second phase, implementation of national level REDD programmes would take place in which a fund would compensate proxy-based results, although possibly not nationwide, with the idea that this would lead to a third phase with a fully fledged coordinated national approach and payments based on real, measured carbon savings from reduced emissions and increased sequestration. The question of whether these payments will be market or fund sourced may be left conveniently vague for the time 
being, with reference in the policy documents to mixed systems at least in the short term. We may in fact be into the post-post-Kyoto period before this decision has to be tied down. One possible outcome in the meantime is that deforestation credits might be marketed, while credits for degradation, sustainable forest management and forest enhancement (in REDD+), which are more difficult to measure and verify, are compensated through a fund. It is hard to imagine how forest conservation credits could ever be treated as offsets, so these in any case are likely to require a fund.

Most ideas designed to save the world go through a hype cycle: first, eureka!, and a phase of euphoria during which almost everyone falls in love with them; then a period of major disillusionment when it appears that they are much more difficult to implement than first thought, that they are not so powerful after all, and that they have lots of drawbacks too. But with the best of them, a slow process may start in which the seeds of the original ideas begin to germinate and develop slowly into a mature stand. We seem to be entering the second of these phases with balanced contributions such as that of Corbera, Estrada and Brown. but also with recent sharp attacks by Greenpeace (2009) on the Noel Kampff project in Bolivia, a very early REDD pioneer project which was designed as an experiment and which inevitably got some things wrong; not to speak of the more extreme views recently expressed by a few NGOs, e.g. portraying REDD as Reaping profits from Evictions, land grabs, Deforestation and Destruction of biodiversity (IEN 2009). Critiques of REDD are likely to get more intense in the near future. However, if approached in small, sensible steps, for example by working first on reducing degradation in low-value forests, REDD may survive the down draught of the hype cycle by demonstrating its ability to bring about moderate improvements in forest biomass losses and in enhancement, and thus play a positive if modest role in the battle to stabilise emissions.

Open Access This article is distributed under the terms of the Creative Commons Attribution Noncommercial License which permits any noncommercial use, distribution, and reproduction in any medium, provided the original author(s) and source are credited.

\section{References}

Börner J, Wunder S, Wertz-Kanounnikoff S, Rügnitz Tito M, Pereira L, Nascimento N (2009) Direct conservation payments in the Brazilian Amazon: scope and equity implications. Ecol Econ (in press, available online 4 Dec 2009)

Economist (2009) Last gasp for the forest. Sept 26 issue

Greenpeace (2009) Carbon scam: Noel Kempff climate action project and the push for sub-national forest offsets. http://www.greenpeace.org/usa/press-center/releases2/carbon-scam-noel-kempffclim

IEN (2009) Indigenous environmental network: REDD: reaping profits from evictions, land grabs deforestation and destruction of biodiversity. www.ienearth.org/REDD/redd.pdf

Reuters (2009) Forest-CO2 scheme will draw organised crime: interpol. http://www.alertnet.org/ thenews/newsdesk/JAK500718.htm

Stern Commission (2007) The economics of climate change. HM Treasury, London

The Age (2009) Carbon scandal snares Australian. http:/www.theage.com.au/business/carbonscandal-snares-australian-20090903-f9yy.html 